\title{
New locations and distribution of the alien species Acalipha australis L. (Euforbiaceae) in Azerbaijan
}

\author{
Rena T. Abdiyeva ${ }^{1}$ \\ Institute of Botany, Azerbaijan National Academy of Sciences, \\ Badamdar 40, Baku, AZ1004, Azerbaijan \\ Svetlana A. Litvinskaya \\ Kuban State University, Stavropolskaya st. 149, Krasnodar, \\ 350049, Russia
}

\begin{abstract}
The article is devoted to the introduced species Acalypha australis L., which has recently been actively expanding its secondary range in Azerbaijan. The results of the study of the distribution and new localities of the species in the republic are discussed, the areas are specified, the species composition of phytocenoses is described, the influence of field moisture on the vitality of $A$. australis and the dependence on vertical zoning are considered. The main habitats of the species are garden plots, vegetable gardens, park zones and the sides of small water channels, the introduction of $A$. australis into forest, coastal ecosystems is noted.

Keywords: invasive species, Greater Caucasus, Lesser Caucasus, forest ecosystems, coastal strip, agrocenoses, abundance
\end{abstract}

\section{INTRODUCTION}

Recently, much attention has been paid to the contamination of local floras with alien species. In this regard, one of the priority directions of botanical research is to identify alien species that can further spread from the places of primary introduction and become worst weeds [Vinogradova, Yulia et al., 2018]. One of these species is Acalypha australis L. About 450 species of the genus Acalypha L. are tropical and temperate species [Mabberley, 1987]. A. australis L. - asian copper-leaved annual plant from the family Euphorbiaceae Juss. The plant blooms in July - August, bears fruit in August - September, germinates in spring and summer from a depth of up to $6 \mathrm{~cm}$. Researchers who have studied the biology of the species argue that the ripening of $A$. australis fruits occurs at different times. Most of them slough and clog the soil. Some part (especially in late harvested crops) ends up in the grain. Reproduction capability is up to 300 seeds. The mass of 1000 seeds is $2 \mathrm{~g}$. Favorable soil conditions for the development of the southern copper leaf are light (sandy), medium and heavy clay soils, acidic, neutral and alkaline. Environmentally prefers light shading (light forests) or open areas, demanding of moisture. The existing modern control measures include a combination of agrotechnical and chemical methods [Agroatlas, 2010].

It also naturalized in the Russian Far East, China, Japan, the United States, Philippines and the Australian continent, in many regions of world, including the Caucasus countries, Ukraine, Italy and Turkey [AgroAtlas, 2010; Berezutsky et al., 2002; Duman, Terzioglu, 2009; Efimova et al., 1997; Moisiienko, Vasylieva, 2003]. In Azerbaijan, the species was first discovered in Guba, Gakh and Lankaran districts in 2004 in the garden plots of restaurants and cafes [Mekhtieva, Geltman, 2015].According to literature data, the plant grows naturally along river banks, on sandy or clayey soils, in woodlands and glades. A. australis is a weed in agrocenoses [AgroAtlas, 2010; Duman, Terziolu, 2009; Zhang, Hirota, 2000; Zuoet et al., 2008]. Korea is trying to identify a biological control agent to help control it [Kwon, 2008]. The seeds of $A$. australis can remain viable in the ground for a long period of time, up to 4 - 5 years. This weed is very harmful to crops, despite its small size [AgroAtlas, 2010]. Control measures are the same as for any annual weed. Good results in weed control are achieved with a combination of agronomic and chemical measures. Biocontrol research started in Korea [Kwon, 2008]. In Southeast Asia, A. australis is considered an important medicinal plant for the treatment of dysentery, diarrhea, scrofula, dermatitis, nasal blood flow, hemoptysis, as well as for stopping coughs and treating swollen legs. The leaves are used for snake bites [USDA, 2010].

Taking into account the above, the purpose of the study was to establish locus and new habitats of $A$. australis, characterize the phytocenotic role, as well as establish the invasive status on the territory of the republic.

'E-mail: abdiyeva.rena@mail.ru

Received 06 April 2021; Received in revised form 30 April 2021; Accepted 26 May 2021 


\section{MATERIAL AND METHODS}

Field observations and collection of material were carried out in 2016-2020 years. The study of habitats was carried out by the route method and the method of laying test plots with inspection of all types of ecotopes and associated plant communities with the participation of $A$. australis.

Geobotanical description was carried out according to the methods generally accepted in geobotany [Mirkin, Naumova, 2001; Pedrotti, 2013]. In habitats with the participation of the species, plots of $100 \times 100$ $\mathrm{m}$ were laid, which were divided into smaller counting plots with a volume of $1 \mathrm{~m}^{2}$. On their basis the number of individuals of the species were mapped and counted, the species composition of the community or groupings were registered, the general projective cover of the herbaceous tier, \% and abundance [Braun-Blanquet, 1964] were determined, indicators of moisture ( $\mathrm{Rh}$ ) soils, which were determined in the field conditions were taken.

The taxonomic affiliation of the species was determined taking into account the "Flora of Azerbaijan" [1952-1961] and the World Flora Online database [16]. Statistical calculations and plotting of dependence graphs were carried out in the Statistica 5.0 software using the Microsoft Excel package.

\section{RESULTS AND DISCUSSION}

In 2015-2020 years the administrative regions of the western (Lesser Caucasus (LC)), northwestern, northeastern (Greater Caucasus (GC)), central (KurAraz lowland) and southern parts (Lankaran lowland) of the republic were examined. As a result, the previously discovered and identified new habitats of $A$. australis were clarified in 2017 , in the Khachmaz district in the vicinity of the city Khachmaz and on the territory of the recreation area of the tourist center; in Absheron, in the vicinity of Baku, in green areas; in the vicinity of Shabran district in garden plots of roadside cafes; in 2018 in the Goygol region, in the vicinity of the city of Goygol, in garden and vegetable gardens; in 2018 in the vicinity of Zagatala and Balakan districts, along the coastal part of rivers, narrow water channels crossing both districts, in garden plots, in park zones; in 2019, in some areas of the coastal strip of Lankaran and Astara districts, as well as border areas of Lankaran - Lerik and Lankaran - Masalli districts; in 2020 in the vicinity of Ganja along narrow water channels crossing the city (Fig. 1).With regard to vertical zoning, it has been established that the area starts from lowland (0-50 m above sea level) to the upper mountain belt (1200 m above sea level). According to the botanical - geographic zoning of Azerbaijan [Mamedov, 2014], the identified locus of $A$. australis are located in the GC western, GC Quba, LC northern and the Lankaran lowland botanical and geographical regions.

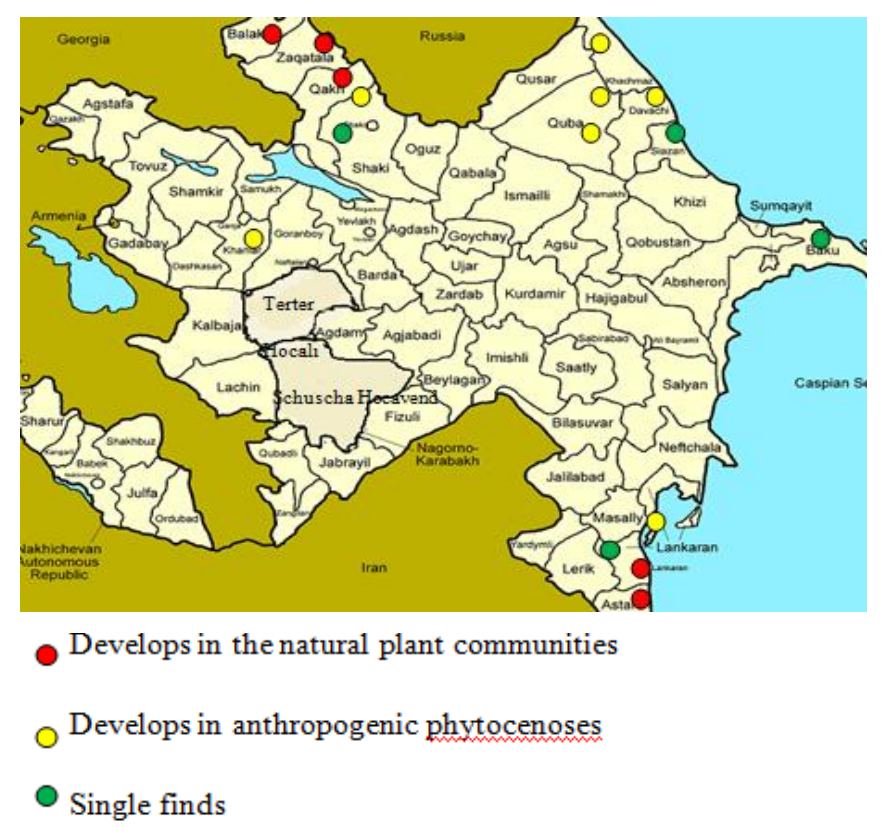

Figure 1. Invasive part of the Acalipha australis range in the administrative regions of Azerbaijan for 20152020 years.

As follows from figure 1, the role of $A$. australis in different parts of the republic is ambiguous. In Zagatala, Gakh, Balakan, Lankaran, Astara districts, it manifests itself as an agriophyte, developing natural areas, in Khachmaz, Shabran, Goygol, Guba, Lerik districts as epecophyte, naturalizing in anthropogenic territories, and single specimens found in Absheron indicate that here the species manifests itself as an ephemerophyte, temporarily present in anthropogenic and semi-natural habitats for one to two years and then disappearing (Fig. 1). The main places of localization of A. australis in natural habitats are the environs of the river Katekhchay (Balakan district), forest area of Lekit (Gdakh district), forest massif of Tarikhler village (Zagatala district), the outskirts of forest areas of the Zagatala State Reserve (Zagatala - Balakan area) (Fig. 2, a), psammophytic littoral communities of the coastal zone (Lankaran, Astara districts) (Tab.1).

In anthropogenized places, A. australis participates in weed groups with other invasive species that have naturalized here (Amaranthus retroflexus L., Ambrosia 
Table 1. Species composition of phytocenoses in the localization of Acalypha australis.

\begin{tabular}{|c|c|c|}
\hline $\begin{array}{l}\text { Name of administrative } \\
\text { region }\end{array}$ & $\begin{array}{c}\text { Botanical-geographical region of } \\
\text { Azerbaijan }\end{array}$ & $\begin{array}{l}\text { Species composition of phytocenosis } \\
\text { (species name/abundance) }\end{array}$ \\
\hline $\begin{array}{l}\text { Gakh district (forest } \\
\text { massive of Lekit) }\end{array}$ & Western Greater Caucasus & $\begin{array}{l}\text { Forest phytocenosis: Carpinus betulus (4), } \\
\text { Acer campestre (3),Corylus avelana (2); } \\
\text { Fraxsinus excelsior (4); } \\
\text { Herbaceous layer: Acalipha australis (3), } \\
\text { Phytolaca americana (1-2), Sambucus ebulus (2), } \\
\text { Dryopterisfilix-mas (2), Bellis perennis (1-2), } \\
\text { Dactylis glomerata (1-2), Geranium molle (2-3), } \\
\text { Melica uniflora (2), Scilla sibirica (2-3), } \\
\text { Oxalis corniculata (3) }\end{array}$ \\
\hline $\begin{array}{l}\text { Zagatala district } \\
\text { (environs of the } \\
\text { reserve) }\end{array}$ & Western Greater Caucasus & $\begin{array}{l}\text { Forest phytocenosis: Fraxsinus excelsior (3), } \\
\text { Corylus avelana (2), Pterocaria pterocarpa (3), } \\
\text { Herbaceous layer: Acalipha australis (3), } \\
\text { Viola arvensis }(3), \text { Fragaria vesca }(2), \\
\text { Echium rubrum (1), Hypericum perforatum (1), } \\
\text { Phytolaca americana (1), Sedum gracile (1), } \\
\text { Calystegia silvestris }(1-2)\end{array}$ \\
\hline $\begin{array}{l}\text { Zagatala district (forest } \\
\text { massive of Tarikhler) }\end{array}$ & Western Greater Caucasus & $\begin{array}{l}\text { Forest phytocenosis: Carpinus betulus (4), } \\
\text { Acer campestre (3), Fraxsinus excelsior (3), } \\
\text { Poulovnia tomentosa }(+) \text {; } \\
\text { Herbaceous layer: Acalipha australis (4), } \\
\text { Phytolaca Americana }(1-2), \text { Sambucus ebulus (2), } \\
\text { Dryopteris filix-mas }(2),(1-2),(1-2), \\
\text { Circaea lutetiana (2-3), Geum urbanum (2), } \\
\text { Polygonum hydropipper (2), Asplenium nigrum (2), } \\
\text { Sedum gracile (+), Oxalis corniculata (4) }\end{array}$ \\
\hline $\begin{array}{l}\text { Balakan district (near } \\
\text { Katekh) }\end{array}$ & Western Greater Caucasus & $\begin{array}{l}\text { Forest phytocenosis: Diospuros lotus (3), } \\
\text { Corylus avelana (2); } \\
\text { Herbaceous layer: Acalipha australis (3-4), } \\
\text { Sambucus ebulus (2), Trifolium ambiguum (2), } \\
\text { Plantago major (2), Rumex acetosella (2), } \\
\text { Mentha longifolia (1), Teucrium polium (2), } \\
\text { Eryngium caucasicum (2), Erigeron annua (1), } \\
\text { Galinsoga parviflora (2) }\end{array}$ \\
\hline $\begin{array}{l}\text { Lankaran region } \\
\text { (coastal strip) }\end{array}$ & Lankaran lowland & $\begin{array}{l}\text { Herbaceous groupings: Acalipha australis (1-2), } \\
\text { Caccile euxina (1), Pulicaria dizett, } \\
\text { Teucrium hyrcanum (1), Artemisia annua (3), } \\
\text { Aster tripolium (2), Ranunculus sp. (2), } \\
\text { Ligustrum vulgare (2), Sonchus arvense (1) }\end{array}$ \\
\hline
\end{tabular}

artemisiifolia L., Erigeron canadensis L., E. bonariensis L., Galinsoga parviflora Cav., Erigeron annuus (L.) Pers., Xanthium strumarium L., X. spinosum L., Bambusa vulgaris Schreb., Phytolacca americana L., Ailanthus altissima (Mill.) Swingle.), as well as representatives of weed-field local flora (Convolvulus arvensis L., Mentha aquatica L., Urtica dioica L.). During the study, we drew attention to the following regularity - in areas with high annual precipitation $(600-1600 \mathrm{~mm})$ [Mamedov et al.,
2010] and a well-developed river network and channels in Qakh, Zagatala, Lankaran A. australis spreads much faster, capturing more and more new areas. It should also be noted that mudflows formed as a result of heavy rainfalls submerging local villages, thus spreading the seeds of not only A. australis, but also other invasive species, play an important role in the distribution of the species in these districts. An example is the mudflows that took place in August 2019, in the Qakh and Zagatala 


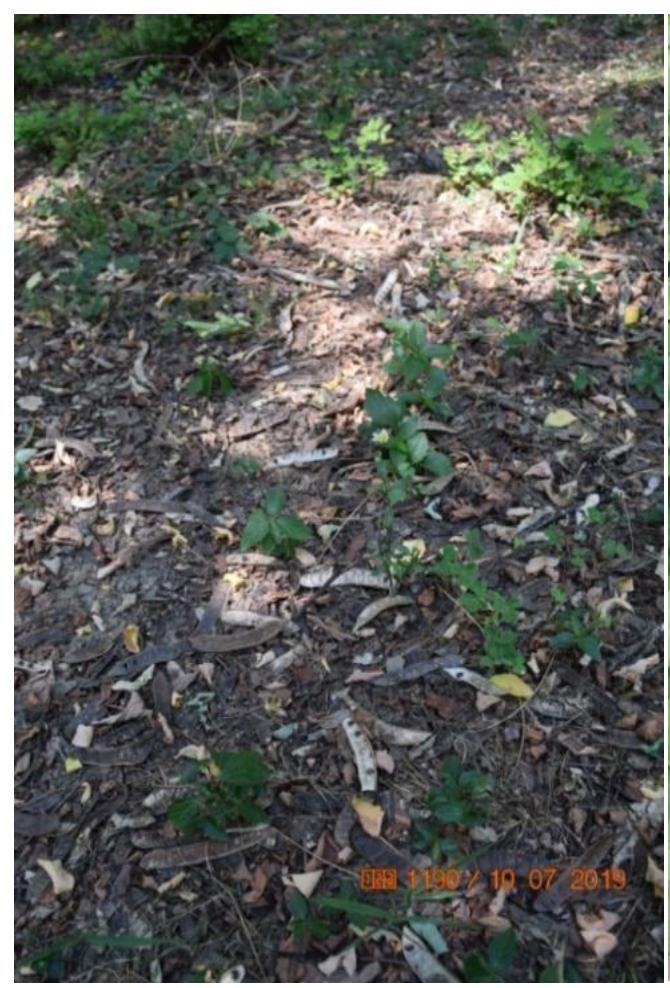

a)

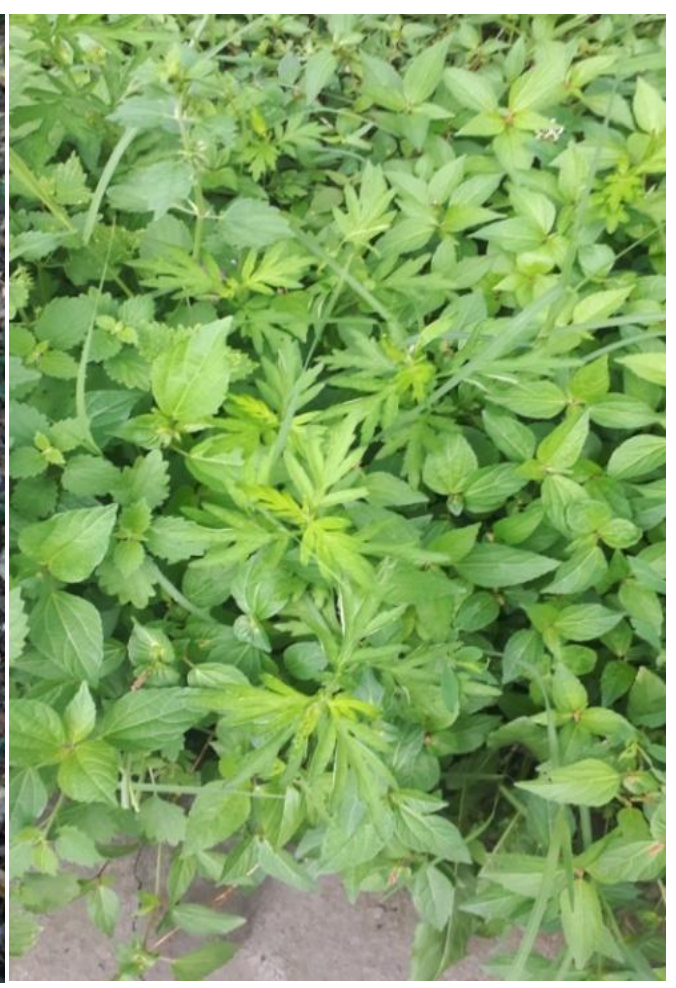

b)

Figure 2. Acalipha australis: a) on the territory of the Zagatala State Nature Reserve (07.07.2019); b) on the outskirts of the village of Mukhakh together with Ambrosia aretmisiifolia L.(15.08.2021).

districts, flooding a large number of villages. As known, the Absheron and Kur-Araz lowlands are arid territories of the republic, with very low annual precipitation (200 $\mathrm{mm}$ ) [Museibov, 1998; Mamedov et al., 2010], the absolute air temperature in late spring here can reach $+25 \mathrm{C}^{\circ}$, and in summer and early autumn it can rise $+40+45 \mathrm{C}^{\circ}$, which is extremely unfavorable for $A$. australis and is a limiting factor for plants in these places. In other areas with an average rainfall (500$1000 \mathrm{~mm}$ ), this plant is still reclaiming heavily irrigated areas, i.e. garden plots and parks.

Since soil moisture is important for A. australis, we decided to find out the optimal values of field moisture for this species, which we measured in all habitats of this plant. As a result, we have established that the optimal humidification conditions are in the range of $45-75 \%$, with a lower limit of $40 \%$ and an upper limit of $75-80 \%$ (Fig. 3).

We also decided to find out how the mechanical control of the plant affects the abundance and recovery of A. australis. In horticultural phytocenoses, 3-year observations were carried out using a systematic collection of individuals of the species. For this, plots with an area of $1 \times 1 \mathrm{~m}$ were selected with a projective species coverage of at least $75 \%$. As follows from Fig. 4 in the second year of observations, the recovery of the species did not decrease significantly and was preserved most likely due to the seed bank in the soil, however, in the third year of observations, it decreased by more than $50 \%$. It should be noted that a similar

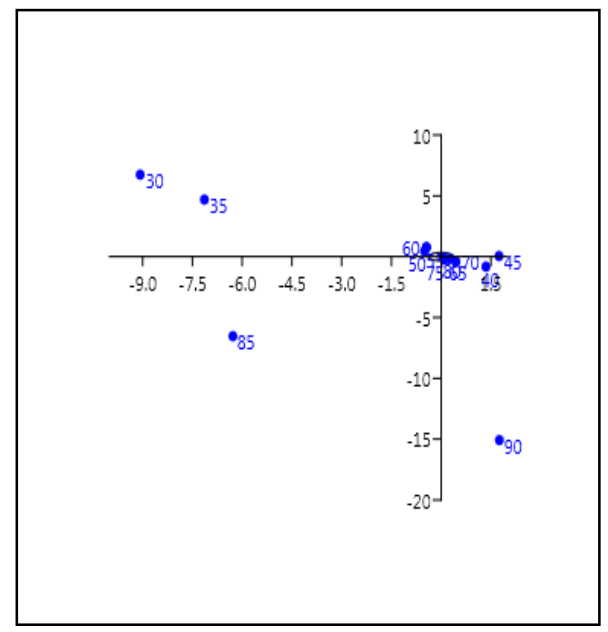

a) Correspondense analysis (CA) 


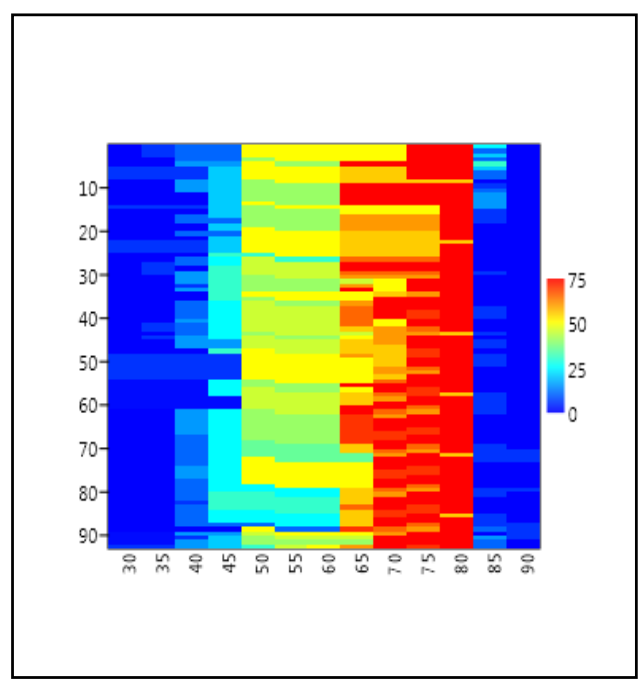

b) Matrix plot

Figure 3. Dependence of the abundance of Acalipha australis on the moisture regime in the range of 30-90\% at the sites: (a) taking into account the analysis (CA); (b) taking into account the construction of matrices (the spectrum of the color range from 0 to 75 and higher means the projective cover (\%) of the species at the survey sites).

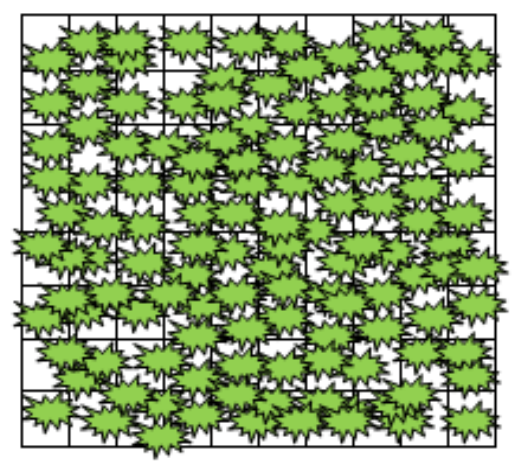

2018

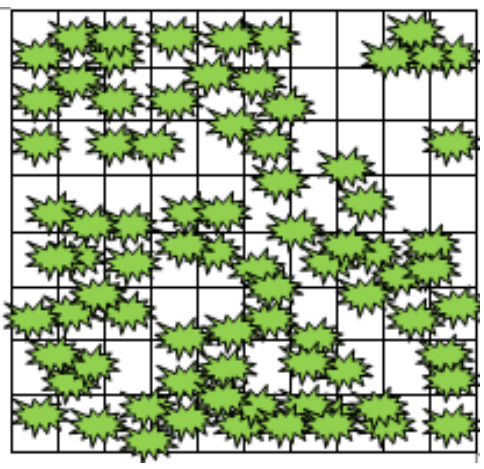

2019

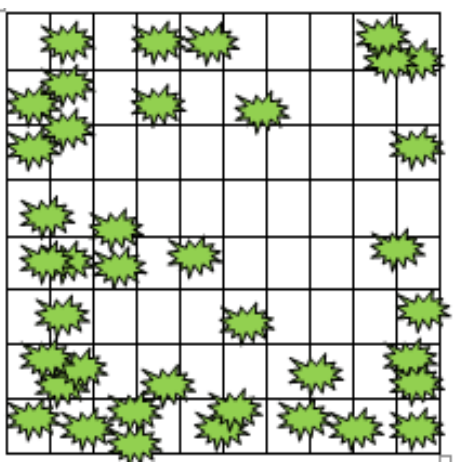

2020

Figure 4. Dynamics of recovery of A. australis $\frac{m_{m}}{3}$ (under mechanical impact on the test site $1 \times 1 \mathrm{~m}$ : 2018 - 95\% projective cover; 2019 - 70\%; 2020 - 25\%).

experience with another malicious naturalized invasive weed Amaranthus retroflexus showed that this species is more viable than $A$. australis. It has reduced its area by only $30 \%$. Thus, $A$. australis, having a high viability in the event of mechanical action, decreases its abundance in 2-3 years. However, it should be taken into account the great laboriousness of this process and in some cases (cleaning the herbaceous layer of forests) the unacceptability and impossibility of its use.

\section{CONCLUSION}

At present we are witnessing the first stages of successful adaptation of $A$. australis, which leads to its gradual development of new territories. Taking into account the geographical origin and the nature of distribution and phytocenotic features of $A$. australis considered in the article, it is easy to come to the conclusion that the population of the species in Azerbaijan is an invasive one. The status of the species can be assessed as an epecophyte, although there are also special cases in which it behaves like an agriophyte. The population has the prerequisites for further successful expansion. This is facilitated by the high abundance in the places of growth, abundance and variability of fertility, availability of suitable biotopes (humidity) and favorable climatic conditions. The limiting factor for distribution is most likely climatic conditions. In this regard, the expansion of the species in the arid zones of the republic will be much weaker or not at all. As is known, many biological invasions are characterized by a "log" phase - a period of slow initial dispersal, during which the species does not show high activity. This phase is then followed by a "lag" phase - a phase of rapid expansion, or spontaneous 
settlement. Of all the surveyed parts of the republic, the A. australis population in the northwest and south of the republic is in a "lag" phase. In the northeast and west, the population is slowly expanding, which is associated with the local suitability of neighboring ecotopes, i.e. is in the "log" phase. Thus, the species has all the prerequisites for further settlement in the republic. The research results show that locus of A. australis are located in the northwestern part of Azerbaijan and in the Lankaran lowland. It was also established that, in relation to water, A. australis is a mesophyte, not resistant to agromechanical measures. In favorable climatic and soil conditions, A. australis is able to form monospecific thickets, compete with local plants and becomes a dangerous aggressive weed for agriculture, cities and population, creates a real threat of contamination of protected areas (Zagatala State Reserve, Goygol National Park). All this creates the need to develop measures to control the number of this species. Given the high invasive potential of $A$. australis, further research into the biology and ecology of the species is needed.

\section{REFERENCES}

Abdieva R.T. (2018) The list of invasive flora of Azerbaijan. Baku: 44 p.

AgroAtlas (2010) Interactive agricultural ecological atlas of Russia and neighboring countries: Economic plants and their diseases, pests and weeds (Online Database). University of St. Petersburg. http://www. agroatlas.ru/.

Alexeev Y.E., Laktionov A.P., Pilipenko V.N., Isaev A.A., Berezutsky N.I., Vasykov M.A., Vasykov V.M., Panin A.V., Sukhorukov A.P., Hudyakova L.P. (2002) Floristic findings in Saratov and Pensa Regios. Botanicheskiy Zhurnal (St. Petersburg), 87(3): 149153. [Алексеев Ю.Е., Лактионов А.П., Пилипенко В.Н., Исаев А.А., Березуцкий Н.И., М.А. Васыков, Васыков В.М., Панин А.В., Сухоруков А.П., Худякова Л.П. (2002) Флористические находки в Саратовской и Пензенской областях. Ботанический журнал (Санкт-Петербург), 87 (3): 149-153]

Braun-Blanquet J. (1964) Pflanzensociologie. Wien New York. 865 p.

Duman H., Terzioğlu S. (2009) Acalypha (Euphorbiaceae): a new genus record for Turkey. Phytologia Balcanica, 15(2): 171-173.

Efimova V.A., Komzha A.L., Popov K.P. (1997) New records of the adventive plants in the Central
Caucasus. Botanicheskii Zhurnal (St. Petersburg), 82(3): 149-153. [Ефимова В.А., Комжа А.Л., Попов К.П. (1997) Новые сведения о появлении всходов на Центральном Кавказе. Ботанический журнал (Санкт-Петербург), 82(3): 149-153]

Flora of Azerbaijan in 8 Vol. AN Azerb. SSR.- Editor: I.I. Karjagin (1950.-V.1-364p; 1952.-V.2- 316p; 1953.-V.4.-379p; 1955.-V.5.-567p; 1955.-V.6-536p; 1957.-V.7-635p; 1961.-V.8.-688p.); Editor D.I. Sosnovsky, I.I. Karjagin (1952.-V.3-400p.) [Флора Азербайджана. В 8т. Баку Ж АН Азерб. ССР.Редактор И.И. Карягин (1950.-т.1-364c; 1952.-т.2316c; 1953.-т.4.-379c; 1955.-т.5.-567c; 1955.-т.6536c; 1957.-т.7-635c; 1961.-т.8.-688c.); Редактор Д.И. Сосновский, И.И. Карягин (1952.-т.3-400с.)]

Kwon O. (2008) Status of weed biological control utilizing insects in Korea. Entomological Research, 38 (1): 86-91.

Mamedov G. (2014) National Atlas of the Republic of Azerbaijan, Baku. 244 p. [Мамедов Г. (2014) Национальный Атлас Азербайджанской Республики, Баку: 244 c. [Mamedov G. (2014) National Atlas of the Republic of Azerbaijan, Baku. 244 р. [Мамедов Г. (2014) Национальный Атлас Азербайджанской Республики, Баку: 244 c].

Mekhtieva N.P., Geltman D.V. (2015) Acalypha australis (Euphorbiaceae) - a new alien species for the flora of Azerbaijan. Botanicheskiy journal, 100(4): 403-406. [Мехтиева Н.П., Гельтман Д.В. (2015) Acalypha australis (Euphorbiaceae) - новый чужеродный вид для флоры Азербайджана . Ботанический журнал, 100(4): 403-406]

Mirkin B.M., Naumova L.G. (2001) Modern vegetation science. Moscow. Publishing house Logos. Moscow: LogosPress, 264 р. [Миркин Б.М., Наумова Л.Г. (2001) Современная наука о растительности. Москва. Изд-во Логос, 264 с.]

Moisiienko I.I., Vasylieva T.M. (2003) Acalypha australis L. (Euphorbiaceae) in Ukraine [Abstract]. Ukrayins'kyi Botanichnyi Zhurnal. 60(5): 537540. [Моисиенко И. И., Васильева Т. М. (2003). Acalypha australis L. (Euphorbiaceae) в Украине [Аннотация]. Украинский ботанический журнал, 60(5): 537-540]

Pedrotti F. (2013) Plant and vegetation mapping (Geobotany studies) edition by Springer-Verlag Berlin Heidelberg. 5(3): 275.

USDA (2021) Weed risk assessment for Acalypha australis L. (Euphorbiaceae) - Asian copperleaf. https. www. aphis.usda.gov/plant 
World Flora Online (2020) WFO. Available at http:// www.worldfloraonline.org

Vinogradova Y., Pergl J., Essl F., Hejda M., Kleunen M. (2018) Invasive alien plants of Russia: insights from regional inventories Biological Invasions, 20(8): 1931-1943.

Zhang Z., Hirota S. (2000) Chinese Colored Weed Illustrated Book. 432 pp.

Zuo S.P., Ma Y.Q., Shinobu I. (2008) Ecological adaptation of weed biodiversity to the allelopathic rank of the stubble of different wheat genotypes in a maize field. Weed Biology and Management, 8(3): 161-171.

\section{Acalipha australis L. (Euforbiaceae) yad növün} Azərbaycanda yeni tapılma və yayılma yerləri

\section{Rəna T. Abdiyeva}

AMEA Botanika Institutu, Badamdar şossesi 40, Bakl, AZ1004, Azərbaycan

\section{Svetlana A. Litvinskaya}

Kuban Dövlat Universiteti, Stavropolskaya küç. 149, Krasnodar, 350049 , Rusiya

Məqalədə son illər Azərbaycanda ikinci arealını genişləndirən vo floraya yad olan Acalypha australis L. növünün bəzi xüsusiyyətləri müzakirə edilmişdir. Növün respublika ərazisi üzrə yayılma və yeni yayılma nəticələri müzakirə edilib, arealları dəqiqləşdirilib, fitosezonların növ tərkibi təsvir edilib, A. australis növünün çöl şəraitində torpaq rütubəti, şaquli zonalar üzrə asılılığı tədqiq edilmişdir. Bitki növünün əsas bitdiyi ərazilər bağça və dirrik sahələri, park əraziləri və kiçik su kanallarının kənarlarıdır, eyni zamanda $A$. australis növünün meşə və sahilyanı ekosistemlərə daxil olunması müşahidə edilmişdir.

Açar sözlor: invaziv növlar, Böyük Qafqaz, Kiçik Qafqaz, meşə ekosistemlari, sahil zolağl, aqrosenozlar, bolluq

\section{Новые места нахождения и распространение заносного вида Acalipha australis L. (Euforbiaceae) в Азербайджане}

\section{Рена Т. Абдыева}

Институт Ботаники НАНАзербайджана, Бадамдарское шоссе 40, Баку, AZ1004, Азербайджан

\section{Светлана А. Литвинская}

Кубанский Государственный Университет, Ставропольская ул. 149, Краснодар, 350049, Россия

Статья посвящена инвазивному виду Acalypha australis L., который в последнее время активно расширяет свой вторичный ареал в Азербайджане. Обсуждаются результаты исследования распространения и новых местонахождений вида в республике, уточнены ареалы, описан видовой состав фитоценозов, рассмотрено влияние на жизненность $A$. australis полевой влажности, зависимость от вертикальной зональности. Основными местами обитания вида являются садовые, огородные участки, парковые зоны и обочины малых водных каналов, отмечается внедрение A. australis в лесные, приморские экосистемы.

Ключевые слова: инвазивный вид, Большой Кавказ, Мальй Кавказ, лесные экосистемы, приморская полоса, агроченозы, численность. 